Article

\title{
Skin Penetration and Stability Enhancement of Celastrus paniculatus Seed Oil by 2-Hydroxypropyl- $\beta$-Cyclodextrin Inclusion Complex for Cosmeceutical Applications
}

\author{
Warintorn Ruksiriwanich ${ }^{1, *}$ (i) , Jakkapan Sirithunyalug ${ }^{2}$, Chiranan Khantham ${ }^{2}$, \\ Krot Leksomboon ${ }^{3}$ and Pensak Jantrawut ${ }^{1}$ (D) \\ 1 Pharmaceutical and Natural Products Research and Development Unit, Department of Pharmaceutical \\ Sciences, Faculty of Pharmacy, Chiang Mai University, Chiang Mai 50200, Thailand; \\ pensak.amuamu@gmail.com \\ 2 Department of Pharmaceutical Sciences, Faculty of Pharmacy, Chiang Mai University, \\ Chiang Mai 50200, Thailand; jakkapan.s@cmu.ac.th (J.S.); chirananK@gmail.com (C.K.) \\ 3 Lanna Innovation and Digital Media Development Center, Social Research Institute, Chiang Mai University, \\ Chiang Mai 50200, Thailand; dr.krot.lek@gmail.com \\ * Correspondence: warintorn.ruksiri@hotmail.com; Tel.: +66-53-944338 or +66-86-6076166; Fax: +66-5389-4169
}

Received: 31 July 2018; Accepted: 30 August 2018; Published: 1 September 2018

Abstract: This study aimed to encapsulate Celastrus paniculatus seed oil (CPSO) in 2-hydroxypropyl$\beta$-cyclodextrin (HP $\beta C D$ ) cavities and investigate their biological activity, physicochemical stability, and skin penetration by vertical Franz diffusion cells of the CPSO-HP $\beta C D$ inclusion complex formulations. For biological activity studies-including 2,2-diphenyl-1-picryhydrazyl radical (DPPH) scavenging, metal ion chelating, and inhibition of lipid and tyrosinase inhibition activities-the CPSO-HP $\beta$ CD inclusion complex exhibited lower inhibition activity than free CPSO. CPSO-HP $\beta$ CD dispersion, serum, and gel formulations were prepared. All formulations containing the CPSO-HP $\beta C D$ inclusion complex showed no significant changes in physical characteristics after three months' storage. The percentages of oleic acid remaining in all formulations were over $80 \%$ of the initial amount during a three-month stability study. For the skin-penetration study, compared to other formulations, the CPSO-HP $\beta C D$ serum formulation exhibited the highest cumulative amount of oleic acid in the whole skin and flux through receptor fluid, after six hours, of $32.75 \pm 1.25 \mu \mathrm{g} / \mathrm{cm}^{2}$ and $1.02 \pm 0.15 \mu \mathrm{g} / \mathrm{cm}^{2} / \mathrm{h}$, respectively. The CPSO-HP $\beta C D$ serum formulation also showed the proper viscosity. Hence, the CPSO-HP $\beta C D$ inclusion complex will be beneficial for the further development of cosmeceutical products.

Keywords: Celastrus paniculatus seed oil; cosmeceutical; 2-hydroxypropyl- $\beta$-cyclodextrin inclusion complex; skin penetration; stability

\section{Introduction}

Celastrus paniculatus is a member of the Celastraceae family, which is a large woody climber (called a climbing shrub) with a yellow corky bark [1]. It is a native of the Indian continent but is known to grow wildly in Indonesia, Laos, Malaysia, Myanmar, and Thailand, as well as numerous Pacific islands [2]. The plants exhibit varying degrees of therapeutic values, some of which include its use in the treatment of cognitive dysfunction, epilepsy, insomnia, rheumatism, gout, and dyspepsia [3]. The oil from its seeds, which are the most commonly used plant part, is rich in oleic acid (54.42\%), which is the main fatty acid in the oil, together with palmitic acid (20.0\%), linoleic acid (15.51\%), and stearic 
acid (4.18\%) [4]. In Northern Thailand, Celastrus paniculatus seed oil (CPSO) is used for massages with great benefits, for like muscle pain, paralysis, and joint stiffness from arthritis. Moreover, fatty acids, and especially oleic acid, have been reported for their antioxidant and anti-inflammatory activities $[5,6]$, which may benefit topical skin applications. Our previous study reported that CPSO exhibits potent tyrosinase inhibition activity over the standard kojic acid, ascorbic acid, and arbutin [7]. However, the oil is oxidized during storage and processing, which affects its quality, stability, and safety [8]. Moreover, CPSO leaves a yellow-orange residue on the skin after application that cannot be removed by soap and water. CPSO, as the oily formulation, may not also be suitable for the delivery of CPSO active components into the skin.

Cyclodextrins are ring molecules with a remarkable ability to increase solubility and stabilize substances by including guest molecules within internal cavities $[9,10]$. Some derivatives, such as 2-hydroxypropyl- $\beta$-cyclodextrin (HP $\beta C D$ ), possess improved toxicological profiles compared to the parent substance [11]. Since the temporary encapsulation of certain active substances allows HP $\beta C D$ to have controlled release properties [12,13], the aqueous solubility of poor water-soluble compounds can be increased by cyclodextrin inclusion complexes with the functional groups. Thus, the objective of this work was to improve the stability and skin penetration of oleic acid the bioactive compound in CPSO via an inclusion complex using HP $\beta C D$.

\section{Materials and Methods}

\subsection{Materials}

2-hydroxypropyl- $\beta$-cyclodextrin (HP $\beta C D$ ), ethylenediaminetetraacetic acid (EDTA), 2,2-diphenyl-1picryhydrazyl radical (DPPH), vitamin C, kojic acid, ferric chloride, and ferrozine were obtained from Sigma Chemical Co. (St. Louis, MO, USA). Oleic acid was procured from Wako Pure Chemical Industrial Ltd. (Osaka, Japan). L-tyrosine and tyrosinase $(4187 \mathrm{U} / \mathrm{mg}$ ) were obtained from Fluka (Buchs, Switzerland). All other chemical substances were of analytical grade.

\subsection{Preparation of the C. paniculatus Seed Oil}

The C. paniculatus seeds were gathered from the Samoeng district, Chiang Mai, Thailand, from January to June 2013. Voucher specimens No. HRDI 58 C0023-22 were deposited at Highland Research and Development Institute, Thailand. The dried seeds were cold-pressed using a Thai traditional cold-press machine. The yellowish-orange oil was obtained with a percentage yield of $26.09 \% w / w$.

\subsection{Determination of Oleic Acid Contents by HPLC}

Oleic acid was selected since it contains the highest CPSO fatty acid profile. The oleic acid content in CPSO was determined by high performance liquid chromatography (HPLC) (Luna ${ }^{\circledR} \mathrm{C} 18$ $10 \mathrm{~m} 250 \mathrm{~mm} \times 4.60 \mathrm{~mm}$ Column (Phenomenex, Torrance, CA, USA), LC1200UV/VIS detector and LC1100HPLC pump) using the mobile phase of $95 \%(v / v)$ acetonitrile mixed with $5 \%(v / v)$ of $0.1 \%$ $(v / v)$ glacial acetic acid, an injection volume at $20 \mu \mathrm{L}$, a flow rate of $1 \mathrm{~mL} / \mathrm{min}$, and the ultraviolet (UV) detector at $205 \mathrm{~nm}$ [7]. The oleic acid content was determined from the HPLC chromatogram in comparing the standard oleic acid with the oleic standard curve equation: $y=4 \times 10^{-5} \mathrm{x}-0.1649$, $R^{2}=0.99996$.

\subsection{Encapsulation of C. paniculatus Seed Oil in $H P \beta C D$}

The co-evaporation method was used, with some modifications [14]. Briefly, HP $\beta C D$ was dissolved with ethanol (95\%) and mixed with CPSO at the weight ratio (CPSO:HP $\beta C D$ ) of 1:1, 1:2, 1:3, 1:4, and 1:5. Ethanol was eliminated by a rotary evaporator. The percentage yields of each formulation were calculated on a dry-weight basis. 


\subsection{Physicochemical Characteristics of Encapsulated HP $\beta C D$}

\subsubsection{Determination of Maximum Encapsulation}

The concentrations of encapsulation were increased from 16.67 to $50 \% w / w$ at the weight ratio (CPSO:HP $\beta C D$ ) of 1:5, 1:4, 1:3, 1:2, and 1:1, respectively. The highest CPSO encapsulation was the target to involve the highest bioactive compounds in the inclusion complex. The maximum encapsulation was indicated from the maximum concentration, which produced no oil leakage on paper for 12 hours at $25 \pm 2{ }^{\circ} \mathrm{C}$. The inclusion ratio was calculated using Equation (1), whereas the total recovery was calculated using Equation (2) [15].

$$
\begin{gathered}
\text { Inclusion ratio }(\%)=\left(\frac{\text { CPSO content of inclusion complex }}{\text { Initial addition of CPSO }}\right) \times 100 \\
\text { Total recovery }(\%)=\left(\frac{\text { Recovery weight of inclusion complex }}{\text { Initial weight of CPSO }+ \text { HP } \beta \text { CD powder }}\right) \times 100
\end{gathered}
$$

The CPSO content in Equation (1) was calculated from the HPLC analysis of biomarker oleic acid in CPSO, which could calculate the amount of CPSO in the inclusion complex.

\subsubsection{Morphology and Particle Size of Inclusion Complex}

The morphology of the HP $\beta C D$ powder and the inclusion complex in the solid state were determined using a scanning electron microscope (SEM; JSM5410-LV, JEOL, Tokyo, Japan) at 200× and $100 \times$ magnification, with JEOL SemAfore software (Tokyo, Japan). The diameters of the empty and CPSO-loaded inclusion complexes in the form of solutions were determined using dynamic light scattering (DLS), Zetasizer 300HSA (Malvern Instruments, Malvern, UK), based on photon correlation spectroscopy. The analysis $(n=5)$ was carried out for $100 \mathrm{~s}$ at room temperature $\left(27 \pm 2{ }^{\circ} \mathrm{C}\right)$. All samples were diluted 30 times with freshly filtrated Millipore water (Millipore Corp., Bedfore, MA, USA) for particle measurement.

\subsection{Biological Studies of the CPSO-HP $\beta C D$ Inclusion Complex}

The biological activities of the five serial concentrations of inclusion complex were investigated by comparing with non-encapsulated CPSO and standard reagents using the following methods: DPPH radical scavenging assay [16], lipid peroxidation inhibition activity [17], metal ion chelating [18], and tyrosinase inhibition assay [19]. Further, the sample concentrations providing 50\% of each activity $\left(\mathrm{IC}_{50}\right)$ were calculated.

\subsection{Preparation of Formulations}

The dispersion of the inclusion complex (CPSO-HP $\beta C D$ dispersion) was prepared by incorporating $3 \% w / w$ of the CPSO-HP $\beta$ CD inclusion complex into propylene glycol. Briefly, $1 \% w / w$ of Carbopol ${ }^{\circledR} 941$ (Lubrizol, Wickliffe, OH, USA) was dispersed in water with gentle stirring to prepare the stock solution of Carbopol gel. The serum base was prepared using $65 \% w / w$ of propylene glycol and $35 \% w / w$ of the stock solution of Carbopol ${ }^{\circledR}$ gel. The CPSO-HP $\beta$ CD inclusion complex $(3 \% w / w)$ was incorporated into the serum base (CPSO-HP $\beta C D$ serum) and gel (CPSO-HP $\beta C D$ gel) base.

\subsection{Stability of CPSO and CPSO-HP $\beta C D$ Inclusion Complex Formulations}

All inclusion-complex formulations, CPSO, and oleic acid dispersions in propylene glycol were kept in glass vials with aluminum caps and stored at $4 \pm 2,25 \pm 2$, and $45 \pm 2{ }^{\circ} \mathrm{C}(65 \pm 5 \%$ relative humidity) for three months. At the baseline and one, two, and three months, the samples were withdrawn and assayed for physical (separation layer, color change, and $\mathrm{pH}$ ) and chemical stability by HPLC using oleic acid as a marker. 


\subsection{In Vitro Skin Permeation Study}

\subsubsection{Skin Sample}

The abdominal skin of male rats (Sprague-Dawley strain, 150-200 g) was shaved with an electric clipper. The rats were sacrificed, and the abdominal skin was excised. The excess subcutaneous fat was carefully removed. The protocol was approved by the ethical committee of the Faculty of Medicine, Chiang Mai University in Thailand (protocol number: 20/2553).

\subsubsection{CPSO Sample Preparation}

All formulations (CPSO-HP $\beta$ CD dispersion, serum, and gel) contained $3 \% w / w$ of the inclusion complex with a CPSO:HP $\beta C D$ ratio of $1: 3$. Thus, the final concentration of CPSO was $0.75 \% w / w$. Free CPSO in propylene glycol (CPSO oily solution) at $0.75 \% w / w$ was used as a control of the permeation study.

\subsubsection{Skin-Permeation Study}

Skin-permeation studies of oleic acid from various formulations were introduced using vertical Franz diffusion cells [20] having an area between the donor and the receiver chamber of $2.46 \mathrm{~cm}^{2}$ and a volume of the receptor fluid of $13 \mathrm{~mL}$. The receptor fluid contained phosphate-buffered saline (PBS, $\mathrm{pH}$ 7.4), which was constantly stirred at $100 \mathrm{rpm}$ with a small magnetic bar and temperature was controlled at $32 \pm 2{ }^{\circ} \mathrm{C}$ throughout the experiment. The skin was mounted with the stratum corneum side facing upward to the donor compartment, and the subcutaneous side was in contact with the medium. The sample $(1 \mu \mathrm{L})$ was placed directly onto the skin and covered the donor compartment with paraffin film $(n=6)$. The cells were stopped at one, two, four, and six hours. Samples in the receptor fluid were analyzed by HPLC as described before. The skin was cut into small pieces; the oleic acid in the skin was extracted by absolute ethanol under sonication for 10 minutes in an ice bath and filtered. The filtrate was assayed for oleic content by HPLC. Cumulative amounts of oleic acid in the whole skin (WS) and receptor fluid (RF) were calculated.

\subsection{Statistical Analysis}

The results are expressed as mean \pm standard deviation (SD). A Kruskal-Wallis test was used to evaluate the significance of differences at a $p$-value $>0.05$.

\section{Results and Discussion}

\subsection{Physical Characteristics of C. paniculatus Seed Oil (CPSO)}

CPSO has a woody, earthy smell, and is yellowish orange in appearance. The HPLC analysis showed that the CPSO in this study was mainly composed of cis-9-oleic acid ( $43.85 \% w / w)$. Other compounds were also found in the oil, such as palmitic acid $(24.12 \%)$, stearic acid $(3.01 \%)$, and myristic acid $(0.48 \%)$. The active constituents of CPSO have also been reported in several studies, and it is composed of several fatty acids [21-23].

\subsection{Physical Characteristics of the CPSO-HP $\beta C D$ Inclusion Complex}

The inclusion ratio and total recovery of the CPSO-HP $\beta$ CD inclusion complex at various weight ratios are shown in Table 1 . When the encapsulated concentration of CPSO was more than $25 \% w / w$ of CPSO, oil spots on the surface of the paper were observed after standing for 12 hours. The suitable encapsulation of CPSO in HP $\beta C D$ cavities occurred at the weight ratio (CPSO: HP $\beta C D$ ) of 1:3 or 25\% $w / w$ of CPSO. The total recovery was $87.5 \pm 3.4 \%$. Driving forces between HP $\beta C D$ and the bioactive compounds in CPSO, such as fatty acids, have been proposed to explain the complex formation energy, including hydrogen bonds, van der Waals forces, hydrophobic interactions, and the release of high-energy water molecules from the cavity [24]. A previous study reported that hydrogen bonds and 
hydrophobic interactions were detected between a thyme essential oil constituent and $\beta$-cyclodextrin using IR and proton nuclear magnetic resonance $\left({ }^{1} \mathrm{H}-\mathrm{NMR}\right)$ spectroscopy $[25,26]$. Moreover, the main driving force of complex formation is the release of enthalpy-rich water molecules from the hydrophobic cavity of $\mathrm{HP} \beta \mathrm{CD}$ [27]. In the encapsulation process, water molecules are displaced by more lipophilic guest molecules present in the solution, resulting in a nonpolar-nonpolar association and a decrease of the cyclodextrin ring strain; this results in a more stable, lower-energy state [28].

Table 1. The inclusion ratio and total recovery of CPSO-HP $\beta C D$ inclusion complex at various weight ratios.

\begin{tabular}{|c|c|c|c|}
\hline $\begin{array}{l}\text { Weight Ratio } \\
\text { (CPSO:HP } \beta C D)\end{array}$ & $\begin{array}{l}\text { Concentration of CPSO in the } \\
\text { Inclusion Complex }(\% w / w)\end{array}$ & $\begin{array}{l}\text { Inclusion Ratio } \\
\text { (\% of Initial) }\end{array}$ & $\begin{array}{l}\text { Total Recovery } \\
\text { (\% of Initial) }\end{array}$ \\
\hline $1: 1$ & 50.0 & NA & NA \\
\hline $1: 2$ & 33.3 & NA & NA \\
\hline $1: 3$ & 25.0 & $92.4 \pm 0.7^{\mathrm{a}}$ & $87.5 \pm 3.4^{\mathrm{a}}$ \\
\hline $1: 4$ & 20.0 & $95.4 \pm 2.2^{a}$ & $90.3 \pm 2.8^{a}$ \\
\hline $1: 5$ & 16.7 & $94.2 \pm 1.3^{a}$ & $89.6 \pm 1.9^{a}$ \\
\hline
\end{tabular}

$\mathrm{NA}=$ not appreciable. The HP $\beta C D$ in that ratio did not appropriately encapsulate all CPSO content. For each ratio, means with the same letter are not significantly different $(p>0.05)$.

Representative SEM images of HP $\beta C D$ powder, blank HP $\beta C D$, which processed the inclusion procedure and CPSO-HP $\beta C D$ inclusion complex, are illustrated in Figure 1. The HP $\beta C D$ powder before the inclusion procedure had a round porous shape with an average size of about $70 \pm 24 \mu \mathrm{m}$. The blank HP $\beta C D$ had a matte surface, whereas the CPSO-HP $\beta C D$ inclusion complex in solid state showed irregular-shaped crystals with a glossy smooth surface without CPSO excess on their surface at a size of about $554 \pm 78 \mu \mathrm{m}$. The CPSO-HP $\beta C D$ inclusion complex appeared as the mean particle sizes in the solution form of HP $\beta C D$ powder, blank HP $\beta C D$, and the CPSO-HP $\beta C D$ inclusion-complex solutions measured by DLS were $103.30 \pm 11.74,112.71 \pm 6.97$, and $240.95 \pm 13.38 \mathrm{~nm}$ with the pdI of $0.32,0.28$, and 0.39 , respectively.

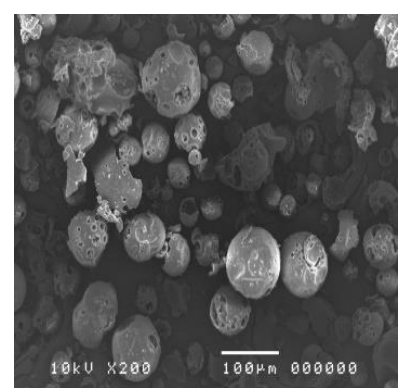

(a)

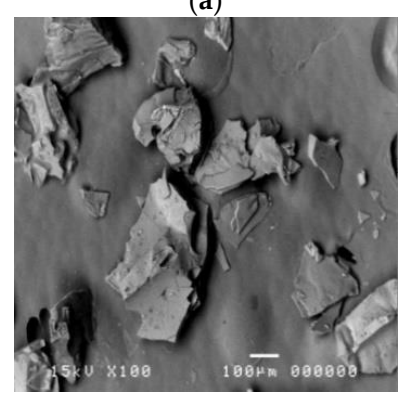

(c)

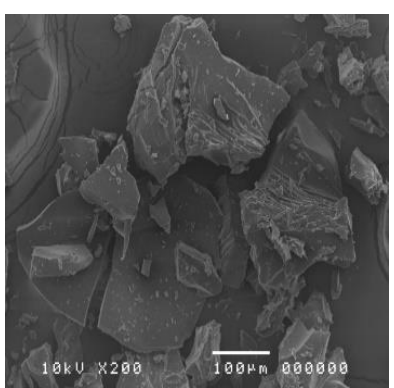

(b)

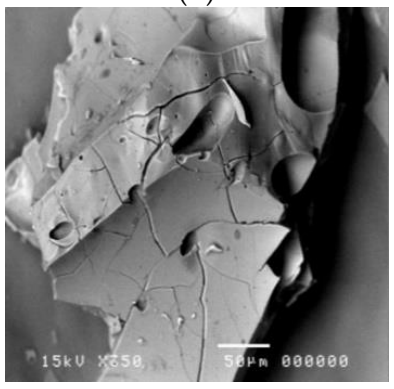

(d)

Figure 1. Scanning electron microscope (SEM) images of (a) HP $\beta C D$ powder; (b) blank HP $\beta C D$ inclusion complex at magnification $200 \times$ and (c) CPSO-HP $\beta C D$ inclusion complex at magnification $100 \times$ and (d) $350 \times$. 


\subsection{Biological Activities of CPSO-HP $\beta C D$ Inclusion Complex}

The CPSO-HP $\beta C D$ inclusion complex exhibited antioxidative activities, including DPPH scavenging, metal ion chelating, inhibition of lipid peroxidation activity, and tyrosinase inhibition activities with $\mathrm{IC}_{50}$ of $564.12 \pm 17.14,3587.21 \pm 25.23,464.87 \pm 11.45$, and $0.19 \pm 0.12 \mathrm{mg} / \mathrm{mL}$, respectively, significantly lower than free CPSO (when not incorporated in HP $\beta C D$ ) by about 20, 11, 8 , and 4 times, respectively (Table 2). This may be due to the shielding effect of HP $\beta C D$, and when hydrophobic bioactive compounds such as CPSO were encapsulated in the bucket-shaped cavity, which may have led to the sustained release action of the active compound [29]. Other researchers have reported that CPSO can be used as a potential source for new drug development in treating various disorders caused by extreme oxidative stress, given its strong antioxidant properties [30]. Tyrosinase inhibition activity has been used to evaluate the skin-whitening effect, and kojic acid, arbutin, and ascorbic acid have been used as well-known standard whitening agents. Since our previous [7] and present study report that CPSO and CPSO-HP $\beta C D$ exhibit high tyrosinase inhibition activity, the biological effect expected from this cosmetic formulation was the whitening effect, and the CPSO-HP $\beta C D$ inclusion complex may have potential to develop cosmeceutical products. Moreover, one mechanism of the tyrosinase inhibitor is to chelate to the tyrosinase enzyme pocket at the copper ion. The metal ion chelation test is the preliminary test for chelation with the protein of the enzyme in the pocket [31]. If the extract shows high metal ion chelation and tyrosinase inhibition activities, it may have high whitening effects via the enzyme chelation mechanism.

Table 2. $\mathrm{IC}_{50}(\mathrm{mg} / \mathrm{mL})$ values of biological activities, including antioxidative and tyrosinase inhibition activities of CPSO-HP $\beta$ CD inclusion complex, compared to CPSO and standard agents.

\begin{tabular}{|c|c|c|c|c|}
\hline \multirow[b]{2}{*}{ Sample } & \multicolumn{3}{|c|}{ Antioxidative Activity (mg/mL) } & \multirow{2}{*}{$\begin{array}{c}\text { Tyrosinase } \\
\text { Inhibition } \\
\text { Activity }\end{array}$} \\
\hline & $\begin{array}{c}\text { DPPH Scavenging } \\
\text { Activity }\end{array}$ & $\begin{array}{c}\text { Metal Ion } \\
\text { Chelating Activity }\end{array}$ & $\begin{array}{l}\text { Inhibition of Lipid } \\
\text { Peroxidation Activity }\end{array}$ & \\
\hline CPSO-HP $\beta C D$ & $564.12 \pm 17.14^{\mathrm{a}}$ & $3587.21 \pm 25.23^{a}$ & $464.87 \pm 11.45^{\mathrm{a}}$ & $0.19 \pm 0.12^{a}$ \\
\hline CPSO & $28.11 \pm 1.97^{b}$ & $314.61 \pm 12.45^{\mathrm{a}}$ & $56.24 \pm 8.85^{\mathrm{b}}$ & $0.04 \pm 0.03^{b}$ \\
\hline Oleic acid & $70.45 \pm 15.14^{c}$ & $26.28 \pm 5.45^{b}$ & $11.25 \pm 1.13^{c}$ & $9.14 \pm 1.14^{\mathrm{c}}$ \\
\hline Ascorbic acid & $0.11 \pm 0.02^{\mathrm{d}}$ & NA & $0.83 \pm 0.02^{\mathrm{d}}$ & $0.09 \pm 0.01^{\mathrm{d}}$ \\
\hline EDTA & NA & $0.48 \pm 0.07^{c}$ & NA & NA \\
\hline Kojic acid & NA & NA & NA & $0.07 \pm 0.01^{\mathrm{d}}$ \\
\hline Arbutin & NA & NA & NA & $0.06 \pm 0.01^{\mathrm{d}}$ \\
\hline
\end{tabular}

$n=3$. Values are expressed as mean $\mathrm{IC}_{50}(\mathrm{mg} / \mathrm{mL}) \pm \mathrm{SD}$ of each test. CPSO = Celastrus paniculatus seed oil. $\mathrm{HP} \beta \mathrm{CD}=2$-hydroxypropyl $\beta$-cyclodextrin. $\mathrm{EDTA}=$ ethylenediaminetetraacetic acid. $\mathrm{NA}=$ not appreciable. For each test, means with the same letter are not significantly different. Thus, means with different letters, (e.g., ' $a$ ' or ' $b^{\prime}$ ) are statistically different $(p<0.05)$.

\subsection{Physical Characteristics of CPSO-HPßCD Inclusion-Complex Formulations}

All formulations containing the CPSO-HP $\beta C D$ inclusion complex-including dispersion (CPSO-HP $\beta C D$ dispersion), serum (CPSO-HP $\beta C D$ serum), gel (CPSO-HP $\beta C D$ gel), and CPSO oily solution formulations-had a yellow appearance. The CPSO oily solution formulation had a separation layer of CPSO on the surface after standing for three hours. The yellow separation layer might have occurred because the CPSO concentration was more than the maximum capacity of oil dispersion in propylene glycol. Moreover, after three months of storage, the color of the CPSO oily solution had changed from yellow to pale yellow, especially when kept at $45^{\circ} \mathrm{C}$. This might be due to the thermal instability of pigment compounds in CPSO. All other CPSO-HP $\beta C D$ formulations had no significant color change with the CIELAB color analysis (data not shown) with a pH of approximately 6.5. 


\subsection{Chemical Characteristics of Oleic Acid in CPSO-HP $\beta C D$ Inclusion Complex and CPSO-HP $\beta C D$ Formulations}

The chemical stability, presented as the percent remaining of oleic acid of various formulations at 4,25 , and $45{ }^{\circ} \mathrm{C}$ for three months, is shown in Figure 2. The non-inclusion complex of the oleic solution showed the lowest remaining content $(64.03 \pm 1.45 \%)$ of oleic acid after three months at every storage temperature. As such, the double bonds in the chemical structures of fatty acids can be oxidized and cause the rapid onset of oil rancidity when exposed to the environment [32]. This result is in agreement with a previous study, which found that the HP $\beta C D$ inclusion complex can protect the inclusion substance against the environment [33]. The CPSO-HP $\beta C D$ inclusion complex at $45^{\circ} \mathrm{C}$ had the lowest remaining oleic acid content $(88.47 \pm 4.14 \%)$, whereas those at $4{ }^{\circ} \mathrm{C}$ and $25^{\circ} \mathrm{C}$ had remaining oleic acid contents of $94.97 \pm 1.71$ and $90.54 \pm 3.41 \%$, respectively. However, no significant difference existed in the remaining content of oleic acid of the CPSO-HP $\beta C D$ inclusion complex among the three storage temperatures.
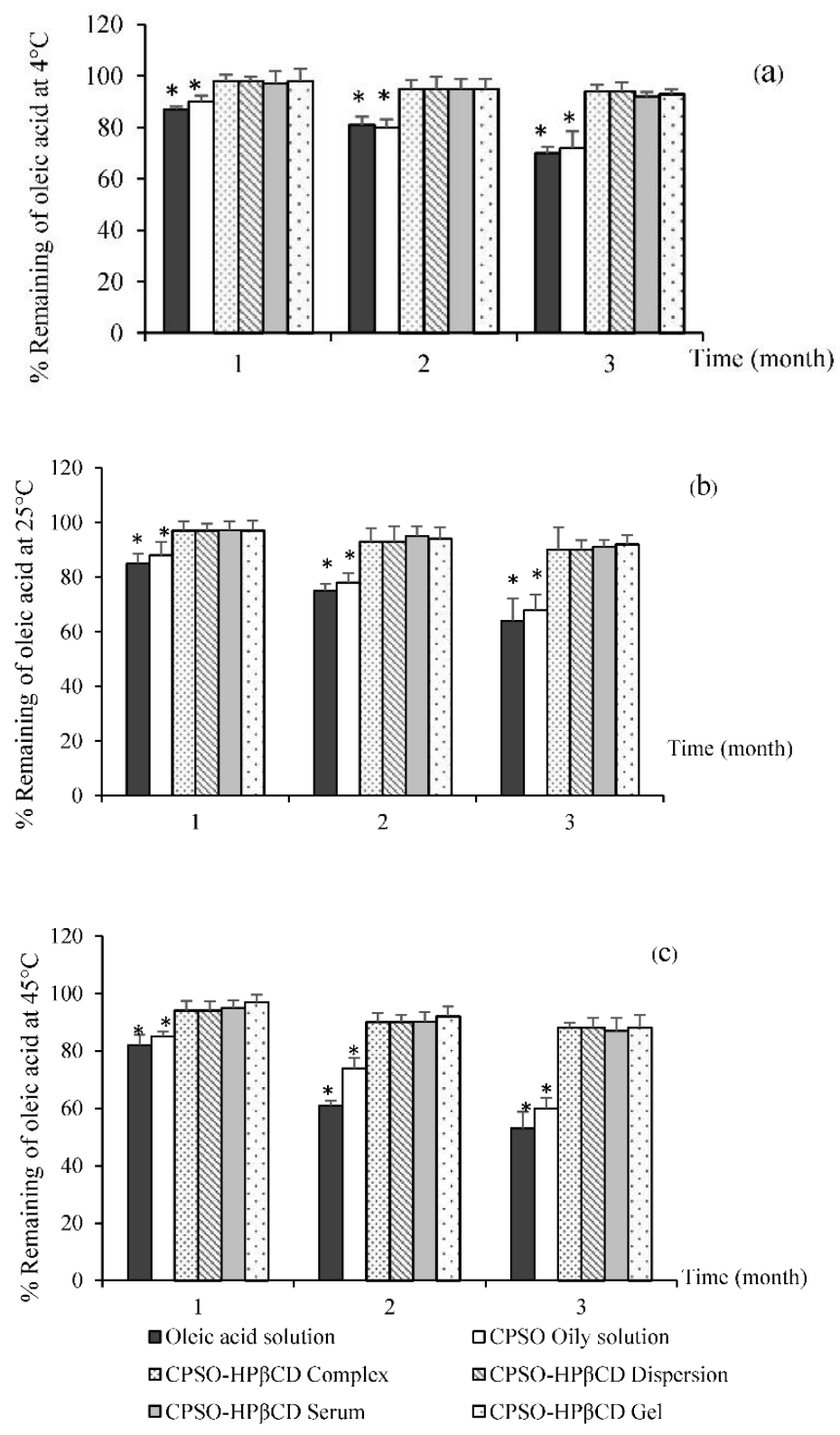

Figure 2. Chemical stability presented as perfect remaining of oleic acid in various formulations at (a) $4{ }^{\circ} \mathrm{C}$, (b) $25^{\circ} \mathrm{C}$, and (c) $45^{\circ} \mathrm{C}$ for three months. 
The chemical stability of each formulation-including CPSO-HP $\beta$ CD dispersion, CPSO-HP $\beta C D$ serum, CPSO-HP $\beta C D$ gel, and CPSO oily solution-was also determined as the amount of oleic acid remaining under the three storage temperatures (Figure 2). The CPSO oily solution had the lowest percentages of oleic acid remaining after three months at 4,25 , and $45^{\circ} \mathrm{C}$ of $72.68 \pm 1.78,68.26 \pm 2.41$, and $60.85 \pm 3.41 \%$, respectively. The remaining percentages' significant decrease $(p>0.05)$ might be because the oleic acid in the CPSO oily solution formulation was not protected by the HP $\beta C D$ structure, leading to a higher oxidation rate by the surrounding environment. This effect might convert oleic acid to ketone or aldehyde, resulting in rancidity. Furthermore, a separation layer of CPSO was found on top of the CPSO oily solution. However, the formulations that contained the CPSO-HP $\beta C D$ inclusion complex (CPSO-HP $\beta C D$ dispersion, serum, and gel) had remaining percentages of oleic acid over $80 \%$ when compared to the initial formulation under all storage temperatures for three months. The CPSO-HP $\beta$ CD dispersion formulation exhibited the highest remaining content of oleic acid after three months at 4,25 , and $45{ }^{\circ} \mathrm{C}$ of $93.56 \pm 1.87,92.71 \pm 2.34$, and $88.00 \pm 2.01 \%$ of the initial amount, respectively.

\subsection{Skin Permeation of CPSO-HP $\beta C D$ Inclusion-Complex Formulations}

The rat-skin model may not be the best choice for a skin-permeation study. However, rodent skin (mice, rats, and guinea pigs) is the most commonly used skin in in vitro percutaneous permeation studies because of its availability. The advantages of these animals are their small size, uncomplicated handling, and relatively low cost [34]. Among rodents, rat skin has more structural similarities to human tissue. Except for rat skin, rodent skin generally shows higher permeation rates than human skin $[35,36]$. Nevertheless, rat skin was used in the skin-permeation assessment [37-40]. Moreover, the permeation kinetic parameters are frequently comparable with human skin. The cumulative amount of oleic acid used as a chemical marker of CPSO in various formulations in the whole skin and the receptor fluid within six hours is shown in Figure 3. The cumulative amount of oleic acid in all formulations gradually increased in both the whole skin and the receptor fluid throughout the experiment. The HP $\beta C D$ inclusion complex containing CPSO in serum formulation (CPSO-HP $\beta C D$ serum) exhibited the highest cumulative amount of oleic acid in the whole skin after six hours of $32.75 \pm 1.25 \mu \mathrm{g} / \mathrm{cm}^{2}$, followed by the CPSO-HP $\beta C D$ dispersion $\left(29.28 \pm 2.12 \mu \mathrm{g} / \mathrm{cm}^{2}\right)$, and CPSO-HP $\beta C D$ gel $\left(25.25 \pm 2.15 \mu \mathrm{g} / \mathrm{cm}^{2}\right)$. The fluxes that permeated through the rat skin into the receptor fluid at six hours for the various formulations were calculated using the linear part of the correlation between the cumulative amount of oleic acid divided by the unit area $\left(2.46 \mathrm{~cm}^{2}\right)$ and time (six hours). The CPSO-HP $\beta C D$ serum exhibited the highest oleic acid flux after six hours, which was $1.02 \pm 0.15 \mu \mathrm{g} / \mathrm{cm}^{2} / \mathrm{h}$, followed by the CPSO-HP $\beta C D$ gel $\left(0.80 \pm 0.12 \mu \mathrm{g} / \mathrm{cm}^{2} / \mathrm{h}\right)$, and CPSO-HP $\beta C D$ dispersion $\left(0.75 \pm 0.01 \mu \mathrm{g} / \mathrm{cm}^{2} / \mathrm{h}\right)$. The CPSO oily solution formulation exhibited the lowest cumulative amount in the whole skin and flux through the receptor fluid after six hours of $15.61 \pm 2.11 \mu \mathrm{g} / \mathrm{cm}^{2}$ and $0.13 \pm 0.01 \mu \mathrm{g} / \mathrm{cm}^{2} / \mathrm{h}$, respectively. All CPSO-HP $\beta C D$ formulations significantly appeared to penetrate the skin more efficiently, whereas the CPSO oily solution exhibited lower penetration with some remaining oil on the skin surface. In addition, superior skin penetration of the inclusion complex was observed in the serum and dispersion formulations (CPSO-HP $\beta C D$ serum-dispersion, $p>0.05$ ) compared to the CPSO-HP $\beta C D$ inclusion complex in gel formulation (CPSO-HP $\beta C D$ gel). This might be due to the viscosity of the formulations and the steric effect of the gel structure, which may retard the skin penetration of oleic acid in CPSO [41]. Moreover, the penetration enhancer effect of propylene glycol [42] — which was used in the CPSO oily solution, CPSO-HP $\beta C D$ dispersion, and CPSO-HP $\beta C D$ serum via pure cosolvent effect [43] or solvating the $\alpha$-keratin structures of the cells [44]—showed lower influence than the HP $\beta C D$ inclusion complex in skin penetration. 


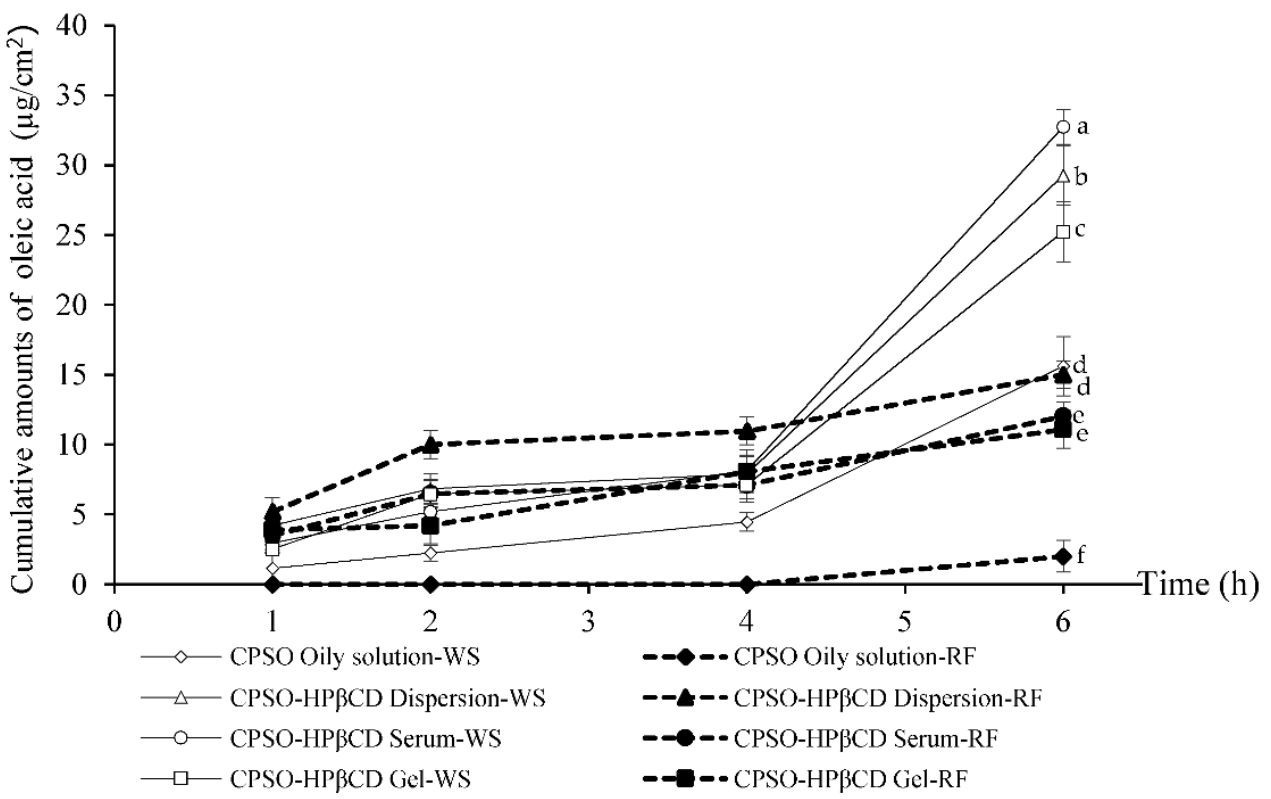

Figure 3. Cumulative amounts of oleic acid in various formulations of the $C$. paniculatus seed oil (CPSO) and hydroxypropyl- $\beta$-cyclodextrin inclusion complex (HP $\beta C D)$ in the whole skin (WS) and receptor fluid (RF) within six hours. At six hours, mean cumulative amounts with the same letter are not significantly different. Thus, means with different letters (e.g., ' $a$ ' or ' $b$ ') were statistically different $(p<0.05)$.

However, oleic acid was found in the receptor fluid in all formulations, which means that CPSO in all formulations, especially in CPSO-HP $\beta$ CD formulations, could penetrate the blood system, which may be due to its small particle size. In the pharmaceutical field, the formulations of an increasing amount of marketed drugs include cyclodextrins because of their capacity to trap drugs into their cavity, enabling their use in drug delivery to facilitate the body-tissue penetration of hydrophilic or hydrophobic drugs $[45,46]$. Even if cyclodextrins could be harmful to the human organism only at extremely high concentrations [47], the toxicity of CPSO should be evaluated to further develop the CPSO-HP $\beta C D$ product. In this study, the abilities of the CPSO oily solution and CPSO-HP $\beta C D$ formulations to be removed after skin application were compared. The results showed that the CPSO-HP $\beta C D$ formulation was easier to remove by water after skin application than the CPSO oily solution. This might be due to the effect of HP $\beta C D$ on CPSO solubility. The aqueous solubility ability was also found in other substance studies (i.e., griseofulvin and phenothiazine cyclodextrin complexation) $[48,49]$. Finally, this study suggests that the inclusion complex in serum formulation may be the most suitable system for topical application, given that it had the highest skin penetration of oleic acid, proper viscosity, and could be removed after skin application. However, the systemic toxicity of this formulation should be a concern.

\section{Conclusions}

CPSO, which is primarily composed of oleic acid, was incorporated in HP $\beta$ CD cavities to improve its stability and skin penetration. The inclusion ratio and total recovery of the CPSO-HP $\beta C D$ inclusion complex were $92.4 \pm 0.7 \%$ and $87.5 \pm 3.4 \%$, respectively. The CPSO-HP $\beta C D$ inclusion complex in a solid state showed irregular-shaped crystals with a glossy smooth surface. The mean particle sizes of the HP $\beta C D$ powder, blank HP $\beta C D$, and CPSO-HP $\beta C D$ inclusion-complex solutions measured by DLS were $103.30 \pm 11.74,112.71 \pm 6.97$, and $240.95 \pm 13.38 \mathrm{~nm}$, respectively. For biological activity studies-including DPPH scavenging, metal ion chelating, inhibition of lipid, and tyrosinase inhibition activities-the CPSO-HP $\beta$ CD inclusion complex exhibited lower inhibition 
activity than free CPSO. This inclusion complex was prepared as CPSO-HP $\beta C D$ dispersion, serum, and gel formulations. All CPSO-HP $\beta C D$ formulations showed no significant change in color, with a $\mathrm{pH}$ of approximately 6.5 , and the oleic acid percentages remaining in all formulations were over $80 \%$ of the initial amount when stored at 4,25 , and $45{ }^{\circ} \mathrm{C}$ for three months. For the rat skin penetration study using Franz diffusion cells, the observant oleic acid was found in the receptor fluid, especially in CPSO-HP $\beta$ CD formulations. The CPSO-HP $\beta C D$ serum formulation exhibited the highest cumulative amount of oleic acid in the whole skin and flux through receptor fluid after six hours of $32.75 \pm 1.25 \mu \mathrm{g} / \mathrm{cm}^{2}$ and $1.02 \pm 0.15 \mu \mathrm{g} / \mathrm{cm}^{2} / \mathrm{h}$, respectively. The CPSO oily solution formulation exhibited the lowest cumulative amount in the whole skin and flux through the receptor fluid after six hours of $15.61 \pm 2.11 \mu \mathrm{g} / \mathrm{cm}^{2}$ and $0.13 \pm 0.01 \mu \mathrm{g} / \mathrm{cm}^{2} / \mathrm{h}$, respectively. This result can be applied to further develop CPSO-HP $\beta$ CD products for topical application. However, the toxicity of CPSO should be evaluated for further experiments.

Author Contributions: Conceptualization, W.R.; Methodology, W.R.; Formal Analysis, K.L.; Investigation, P.J.; Resources, J.S.; Writing-Original Draft Preparation, C.K.; Writing-Review and Editing, W.R. and P.J.; Supervision, W.R.; Project Administration, W.R.; Funding Acquisition, W.R.

Funding: The authors are grateful for the financial support of the Chiang Mai University Junior Research Fellowship Program 2015, the Faculty of Pharmacy, Chiang Mai University Research grant 2016 and the grant from Lanna Innovation and Digital Media Development Centre, Social Research Institute, Chiang Mai University.

Acknowledgments: The authors are grateful for the C. paniculatus seed oil from the Highland Research and Development Institute, Thailand.

Conflicts of Interest: The authors report no conflicts of interest. The authors alone are responsible for the content and writing of this article.

\section{References}

1. Chatterjee, A.; Prakashi, S.C. The Treatise on Indian Medicinal Plants; Niscair: New Delhi, India, 2003; Volume 3, p. 160.

2. Singh, U.; Wadhawani, A.M.; Johri, B.M. Dictionary of Economical Plants of India; Indian council of Agricultural Research: New Delhi, India, 1996.

3. Nadkarni, K.M.; Nadkarni, A.K.; Nadkarni, K.M. Indian Plants and Drugs; Popular Bombay Prakashan Pvt Ltd.: Mumbai, India, 1976; Volume 1, p. 296.

4. Rana, V.S.; Das, M. Fatty acid and non-fatty acid components of the seed oil of Celastrus paniculatus willd. Int. J. Fruit Sci. 2017, 17, 407-414. [CrossRef]

5. Tanojo, H.; Boelsma, E.; Junginger, H.E.; Ponec, M.; Bodde, H.E. In vivo human skin barrier modulation by topical application of fatty acids. Skin Pharmacol. Appl. Skin Physiol. 1998, 11, 87-97. [CrossRef] [PubMed]

6. Ziboh, V.A.; Miller, C.C.; Cho, Y. Metabolism of polyunsaturated fatty acids by skin epidermal enzymes: Generation of antiinflammatory and antiproliferative metabolites. Am. J. Clin. Nutr. 2000, 71 (Suppl. 1), 361S-366S. [CrossRef] [PubMed]

7. Ruksiriwanich, W.; Sringarm, K.; Jantrawut, P. Stability enhancement of Celastrus paniculatus seed oil by loading in niosomes. Asian J. Pharm. Clin. Res. 2014, 7, 186-191.

8. Choe, E.; Min, D.B. Mechanisms and factors for edible oil oxidation. Compr. Rev. Food Sci. Food Saf. 2006, 5, 169-186. [CrossRef]

9. Duchêne, D.; Bochot, A.; Yu, S.C.; Pépin, C.; Seiller, M. Cyclodextrins and emulsions. Int. J. Pharm. 2003, 266, 85-90. [CrossRef]

10. Schmid, G. Cyclodextrin glycosyltransferase production: Yield enhancement by overexpression of cloned genes. Trends Biotechnol. 1989, 7, 244-248. [CrossRef]

11. Kurkov, S.V.; Loftsson, T. Cyclodextrins. Int. J. Pharm. 2013, 453, 167-180. [CrossRef] [PubMed]

12. Citernesi, U.; Sciacchitano, M. Cyclodextrins in functional dermocosmetics. Cosmet. Toilet. 1995, 110, 53-61.

13. Sarveiya, V.; Templeton, J.F.; Benson, H.A.E. Inclusion complexation of the sunscreen 2-hydroxy-4-methoxy benzophenone (oxybenzone) with hydroxypropyl- $\beta$-cyclodextrin: Effect on membrane diffusion. J. Incl. Phenom. Macrocycl. Chem. 2004, 49, 275-281. [CrossRef] 
14. Radhika, P.; Nagabhushanam, M.V.; Ramana, M.V. Preparation and characterization of Lornoxicam solid systems using cyclodextrins for improved bioavailability. Bull. Pharm. Res. 2015, 5, 101-107.

15. Wang, J.; Cao, Y.; Sun, B.; Wang, C. Physicochemical and release characterisation of garlic oil- $\beta$-cyclodextrin inclusion complexes. Food Chem. 2011, 127, 1680-1685. [CrossRef]

16. Tachibana, Y.; Kikuzaki, H.; Hj-Lajis, N.; Nakatani, N. Antioxidant activity of carbazoles from Murraya koenigii leaves. J. Agric. Food Chem. 2001, 49, 5589-5594. [CrossRef] [PubMed]

17. Osawa, T.; Namiki, M. A novel type of antioxidant isolated from leaf wax of eucalyptus leaves. Agric. Biol. Chem. 1981, 45, 735-739. [CrossRef]

18. Decker, E.A.; Welch, B. Role of ferritin as a lipid oxidation catalyst in muscle food. J. Agric. Food Chem. 1990, 38, 674-677. [CrossRef]

19. Shimizu, K.; Kondo, R.; Sakai, K.; Lee, S.; Sato, H. The inhibitory components from Artocarpus incisus on melanin biosynthesis. Planta Med. 1998, 64, 408-412. [CrossRef] [PubMed]

20. Plessis, J.; Egbaria, K.; Weiner, N. Influence of formulation factors on the deposition of liposomal components into the different strata of the skin. J. Soc. Cosmet. Chem. 1992, 43, 93-100.

21. Kabnurkar, R.B. Phytopharmaceutical studies of the topical formulations of Celastrus paniculatus Willd (CELASTRACEAE). J. Pharm. Biomed. Sci. 2012, 17, 1-4.

22. Bhanumathy, M.; Chandrasekar, S.B.; Chandur, U.; Somasundaram, T. Phytopharmacology of Celastrus paniculatus: An overview. Int. J. Pharm. Sci. Drug Res. 2010, 2, 176-181.

23. Arora, N.; Pandey-Rai, S. Celastrus paniculatus, an endangered indian medicinal plant with miraculous cognitive and other therapeutic properties: An overview. Int. J. Pharma Bio Sci. 2012, 3, 290-303.

24. Salústio, P.J.; Feio, G.; Figueirinhas, J.L.; Pinto, J.F.; Cabral Marques, H.M. The influence of the preparation methods on the inclusion of model drugs in a $\beta$-cyclodextrin cavity. Eur. J. Pharm. Biopharm. 2009, 71, 377-386. [CrossRef] [PubMed]

25. Mourtzinos, I.; Salta, F.; Yannakopoulou, K.; Chiou, A.; Karathanos, V.T. Encapsulation of olive leaf extract in $\beta$-cyclodextrin. J. Agric. Food Chem. 2007, 55, 8088-8094. [CrossRef] [PubMed]

26. Del Toro-Sánchez, C.; Ayala-Zavala, J.; Machi, L.; Santacruz, H.; Villegas-Ochoa, M.; Alvarez-Parrilla, E.; González-Aguilar, G. Controlled release of antifungal volatiles of thyme essential oil from $\beta$-cyclodextrin capsules. J. Incl. Phenom. Macrocycl. Chem. 2010, 67, 431-441. [CrossRef]

27. Del Valle, E.M.M. Cyclodextrins and their uses: A review. Process Biochem. 2004, 39, 1033-1046. [CrossRef]

28. Szejtli, J. Introduction and general overview of cyclodextrin chemistry. Chem. Rev. 1998, 98, $1743-1754$. [CrossRef] [PubMed]

29. Bilia, A.R.; Guccione, C.; Isacchi, B.; Righeschi, C.; Firenzuoli, F.; Bergonzi, M.C. Essential oils loaded in nanosystems: A developing strategy for a successful therapeutic approach. Evid. Based Complement. Alternat. Med. 2014, 2014, 1-14. [CrossRef] [PubMed]

30. Arora, N.; Pandey-Rai, S. GC-MS analysis of the essential oil of Celastrus paniculatus Willd seeds and antioxidant, anti-inflammatory study of its various solvent extracts. Ind. Crops Prod. 2014, 61, 345-351. [CrossRef]

31. Khatib, S.; Nerya, O.; Musa, R.; Shmuel, M.; Tamir, S.; Vaya, J. Chalcones as potent tyrosinase inhibitors: The importance of a 2, 4-substituted resorcinol moiety. Bioorg. Med. Chem. 2005, 13, 433-441. [CrossRef] [PubMed]

32. Kouba, M.; Mourot, J. A review of nutritional effects on fat composition of animal products with special emphasis on n-3 polyunsaturated fatty acids. Biochimie 2011, 93, 13-17. [CrossRef] [PubMed]

33. Szente, L.; Szejtli, J.; Szemán, J.; Kató, L. Fatty acid-cyclodextrin complexes: Properties and applications. J. Incl. Phenom. Macrocycl. Chem. 1993, 16, 339-354. [CrossRef]

34. Godin, B.; Touitou, E. Transdermal skin delivery: Predictions for humans from in vivo, ex vivo and animal models. Adv. Drug Deliv. Rev. 2007, 59, 1152-1161. [CrossRef] [PubMed]

35. Roberts, M.E.; Mueller, K.R. Comparisons of in vitro nitroglycerin (TNG) flux across Yucatan pig, hairless mouse, and human skins. Pharm. Res. 1990, 7, 673-676. [CrossRef] [PubMed]

36. Sato, K.; Sugibayashi, K.; Morimoto, Y. Species differences in percutaneous absorption of nicorandil. J. Pharm. Sci. 1991, 80, 104-107. [CrossRef] [PubMed]

37. Imai, T.; Ariyoshi, S.; Ohura, K.; Sawada, T.; Nakada, Y. Expression of carboxylesterase isozymes and their role in the behavior of a fexofenadine prodrug in rat skin. J. Pharm. Sci. 2016, 105, 714-721. [CrossRef] [PubMed] 
38. Krishnaiah, Y.S.R.; Satyanarayana, V.; Karthikeyan, R.S. Penetration enhancing effect of menthol on the percutaneous flux of nicardipine hydrochloride through excised rat epidermis from hydroxypropyl cellulose gels. Pharm. Dev. Technol. 2002, 7, 305-315. [CrossRef] [PubMed]

39. Kunta, J.R.; Goskonda, V.R.; Brotherton, H.O.; Khan, M.A.; Reddy, I.K. Effect of menthol and related terpenes on the percutaneous absorption of propranolol across excised hairless mouse skin. J. Pharm. Sci. 1997, 86, 1369-1373. [PubMed]

40. Herman, A.; Herman, A.P. Essential oils and their constituents as skin penetration enhancer for transdermal drug delivery: A review. J. Pharm. Pharmacol. 2015, 67, 473-485. [CrossRef] [PubMed]

41. Suetake, T.; Sasai, S.; Zhen, Y.X.; Tagami, H. Effects of silicone gel sheet on the stratum corneum hydration. Br. J. Plast. Surg. 2000, 53, 503-507. [CrossRef] [PubMed]

42. Arellano, A.; Santoyo, S.; Martın, C.; Ygartua, P. Influence of propylene glycol and isopropyl myristate on the in vitro percutaneous penetration of diclofenac sodium from carbopol gels. Eur. J. Pharm. Sci. 1999, 7, 129-135. [CrossRef]

43. Goodman, M.; Barry, B.W. Action of penetration enhancers on human skin as assessed by the permeation of model drugs 5-fluorouracil and estradiol I Infinite dose technique. J. Investig. Dermatol. 1988, 91, 323-327. [CrossRef] [PubMed]

44. Sarpotdar, P.P.; Zatz, J.L. Evaluation of penetration enhancement of lidocaine by nonionic surfactants through hairless mouse skin in vitro. J. Pharm. Sci. 1986, 75, 176-181. [CrossRef] [PubMed]

45. Uekama, K.; Hirayama, F.; Irie, T. Cyclodextrin drug carrier systems. Chem. Rev. 1998, 98, $2045-2076$. [CrossRef] [PubMed]

46. Davis, M.E.; Brewster, M.E. Cyclodextrin-based pharmaceutics: Past, present and future. Nat. Rev. Drug Discov. 2004, 3, 1023-1035. [CrossRef] [PubMed]

47. Buschmann, H.J.; Schollmeyer, E. Application of cyclodextrins in cosmetic products: A review. J. Cosmet. Sci. 2002, 53, 185-191. [PubMed]

48. Veiga, M.D.; Díaz, P.J.; Ahsan, F. Interactions of griseofulvin with cyclodextrins in solid binary systems. J. Pharm. Sci. 1998, 87, 891-900. [CrossRef] [PubMed]

49. Lutka, A. Effect of cyclodextrin complexation on aqueous solubility and photostability of phenothiazine. Die Pharm. 2000, 55, 120-123. 